\title{
Tillage, Fungicide, and Cultivar Effects on Frogeye Leaf Spot Severity and Yield in Soybean
}

\author{
Alemu Mengistu, Crop Genetics Research Unit, United States Department of Agriculture, Agricultural Research Service (USDA- \\ ARS), 605 Airways Boulevard, Jackson, TN 38301; Heather M. Kelly, University of Tennessee, Entomology and Plant Pathology, 605 \\ Airways Blvd., Jackson, TN 38301; Nacer Bellaloui, Crop Genetics Research Unit, USDA-ARS, 141 Experiment Station Road, Stone- \\ ville, MS 38776-0350; Prakash R. Arelli, Crop Genetics Research Unit, USDA-ARS, 605 Airways Boulevard, Jackson, TN 38301; \\ Krishna N. Reddy, Crop Production Systems Research Unit, USDA-ARS, 141 Experiment Station Road, Stoneville, MS 38776-0350; \\ and Allen J. Wrather, Division of Plant Sciences, University of Missouri, Portageville, MO 63873
}

\begin{abstract}
Mengistu, A., Kelly, H. M., Bellaloui, N., Arelli, P. R., Reddy, K. N., and Wrather, A. J. 2014. Tillage, fungicide, and cultivar effects on frogeye leaf spot severity and yield in soybean. Plant Dis. 98:1476-1484.

Frogeye leaf spot (FLS) of soybean, caused by Cercospora sojina, has been a problem in the southern United States for many years but has become an increasing problem in the northern United States more recently, causing significant yield losses. This increase in disease severity in the northern United States has been attributed to increased utilization of no-till planting and changes in climate. A field study was conducted at the University of Tennessee, Research and Education Center in Milan, TN from 2007 to 2010 to determine severity in tilled and no-till plots treated with or without fungicide at R3 and R5 growth stages. Three FLS-susceptible cultivars, one each in Maturity Groups III, IV, and V, were treated with pyraclostrobin (Headline) fungicide. Analysis of variance using the area under the disease progress curve

(AUDPC) indicated no significant difference $(P \leq 0.05)$ in disease severity between tilled and no-till plots without fungicide. Fungicide did not significantly reduce disease under no-till, but did under tilled plots. This is the first study showing that no-till plots did not reduce or enhance the severity of FLS when no fungicide was applied. Fungicide application significantly reduced $(P \leq 0.05)$ disease severity and AUDPC and increased yield in tilled plots. The yield gains in tilled, fungicide-treated plots ranged from 1 to $17 \%$. When fungicide was applied, disease severity was not reduced as significantly in no-till as in treated tilled plots, suggesting that fungicide programs under a notill system may require further study to minimize the risk of FLS severity.
\end{abstract}

Frogeye leaf spot (FLS), caused by Cercospora sojina K. Hara, is primarily a foliar disease of soybean (Glycine max (L.) Merr.), even though seeds, pods, and stems can also be infected (9). It was first reported on soybean in Japan in 1915, in the United States in 1924 (13), and is present in most countries around the world (3). It has been reported that $C$. sojina does not overwinter in northern areas, and it has been suggested that it is a problem only in the southern United States (32), but the severity and prevalence of FLS in some north-central states, including Ohio, Wisconsin, and Iowa, has increased during the last few years $(6,16,34)$. The reason for changes in incidence and severity of FLS in some northern states is not clear, but changes in the environment particularly warmer winter temperatures, use of susceptible soybean cultivars, and increased usage of no-till system practices have been proposed as potential causes for recent outbreaks $(6,7,33,34)$. Cruz and Dorrance (6) attributed the increase in FLS severity in Ohio to the ability of $C$. sojina to survive the winters of 2005 to 2007, but stated more research is needed to refine the temperature threshold for $C$. sojina survival, and other forecast variables need to be investigated.

The pathogen overwinters in diseased crop residue and seeds (26). Although seedlings from infected seeds may have FLS lesions on the cotyledons (27), lesions on leaves do not appear for nearly 7 to 14 days after invasion of the host tissue, so they are not visually observed on young expanding leaves (25). Disease incidence of FLS in soybean is dependent on environmental

Corresponding author: Alemu Mengistu,

E-mail: Alemu.mengistu@ars.usda.gov

Accepted for publication 2 May 2014.

http://dx.doi.org/10.1094/PDIS-12-13-1268-RE

(C) 2014 The American Phytopathological Society conditions (9), mainly requiring prolonged moisture for adequate infection of new leaves as they develop. Such conditions result in infection of leaves, stems, and pods throughout the season (12). Specific effects of temperature and moisture on disease development are not well understood. However, a layered pattern of heavily diseased and very lightly diseased leaves can occur on the same plant if dry periods, which are unfavorable for infection, are interspersed with favorable, wet periods. Leaves produced during dry periods may remain relatively symptom-free, whereas leaves produced during wet periods are heavily infected (25). An increase in the acidity of irrigation water was also shown to reduce the severity of FLS (32).

No-till systems involve leaving all crop residues on the soil surface after harvest in an effort to reduce soil erosion caused by wind and water runoff (30). In 1990, federal farm legislation required the adoption of conservation plans that mandated a minimum requirement of $30 \%$ residue cover at the time of crop emergence for land classified as highly erodible (30). However, reduced till and no-till systems are used across most of the soybean production areas of the United States due to reduced costs of production and to minimize soil erosion. A possible consequence to no-till systems is diseases that were less economically important under tilled regimes could become more important under no-till; however, there are no data that support this claim (9).

Pathogen survival in crop residue is thought to be responsible for initiation and development of FLS epidemics in the southern states (9) and for the fact that FLS severity has been considered greater in no-till than in tilled fields. In a study on gray leaf spot (GLS) of corn caused by Cercospora zeae-maydis, there is an association between the severity of this disease and the use of conservation tillage (24). Latterrel and Rossi (11) and Nutter et al. (23) reported that widespread adoption of conservation tillage combined with continuous-corn and large amounts of surface residue are believed to be responsible for the prevalence and severity of GLS throughout the Corn Belt. 
There are no studies on the effects of tillage on development of FLS epidemics. Spores produced on infected cotyledons and infested residue from previous soybean crops may infect young leaves (9), but data to support these claims are not available. The relative contribution of spores from no-till residue compared to spores originating from tilled residue for infection of young leaves is unknown. Lesions do not appear on leaves for nearly 7 to 14 days after infection of the host tissue, so they are not visually observed on young expanding leaves (25).

FLS is managed primarily by planting resistant cultivars, applying foliar fungicides to susceptible cultivars between growth stages R2-R5 (full bloom through beginning seed fill), planting diseasefree seeds, and crop rotation (9). Three dominant resistance genes have been identified in soybean that confer resistance to $C$. sojina

Table 1. Cercospora sojina isolates collected from the Research and Education Center in Milan, TN in 2010 tested for quinone outside inhibitor fungicide sensitivity

\begin{tabular}{lcc}
\hline Culture & Year collected & ${\text { Reaction to } \mathbf{Q o I}^{\mathbf{a}}}$ \\
\hline TN160 & 2007 & $\mathrm{~S}$ \\
TN179 & 2007 & $\mathrm{~S}$ \\
TN204 & 2007 & $\mathrm{~S}$ \\
CS10117 & 2010 & $\mathrm{~S}$ \\
CS10116 & 2010 & $\mathrm{R}$ \\
CS10120 & 2010 & $\mathrm{R}$ \\
CS10127 & 2010 & $\mathrm{R}$ \\
\hline
\end{tabular}

a In vitro conidial germination assay was conducted with azoxystrobin + salicylhydroxamic acid (SHAM)-amended potato dextrose agar as described by Zhang et al. (37) to determine if each isolate was resistant $(\mathrm{R})$ or sensitive $(\mathrm{S})$ to quinone outside inhibitor (QoI) fungicide. Not indicative of proportion of QoI resistance presence in time.
$(21,20)$. Yield loss from FLS is mainly due to reduced photosynthetic area and premature defoliation (2) resulting in reductions of 10 to $60 \%$ (13). FLS can cause significant yield suppression, and its management is through fungicide applications. Fungicide has become a significant part of soybean disease management programs in the northern and southern United States when diseaseresistant soybean is not planted or unavailable. Fungicides to control FLS have been utilized as a means to assess the impact of diseases on yield under various sets of environments $(1,7)$. Using FLS severity and yield differences to measure the impact of FLS in both tilled and no-till plots have not been investigated. Research results in no-till experiments show that yield was greater and FLS severity was reduced when fungicides were applied at growth stage R3 and R5 (8) for FLS management (6,29). Unfortunately, strobilurin-resistant isolates of $C$. sojina have been detected in Illinois, Kentucky, Tennessee, Alabama, Arkansas, Mississippi, Missouri, and Louisiana since 2010 (5), complicating fungicide recommendations (36). The objective of this study was to measure FLS severity and soybean yield under tilled and no-till cultivation with and without application of pyraclostrobin (Headline) at R3 and R5 growth stages.

\section{Materials and Methods}

Field plot design and treatments. A field study was conducted from 2007 through 2010 at Milan Research and Education Center, University of Tennessee, Milan, TN. This research location has been a center for no-till research since the 1980s, and the field where the study was conducted has a history of high FLS disease pressure. The soil was a Memphis silt loam (Fine-silty, mixed, active, thermic Typic Hapludalfs). Weed management systems were designed using the University of Tennessee recommendations using pre- and postemergent herbicide applications in all plots.

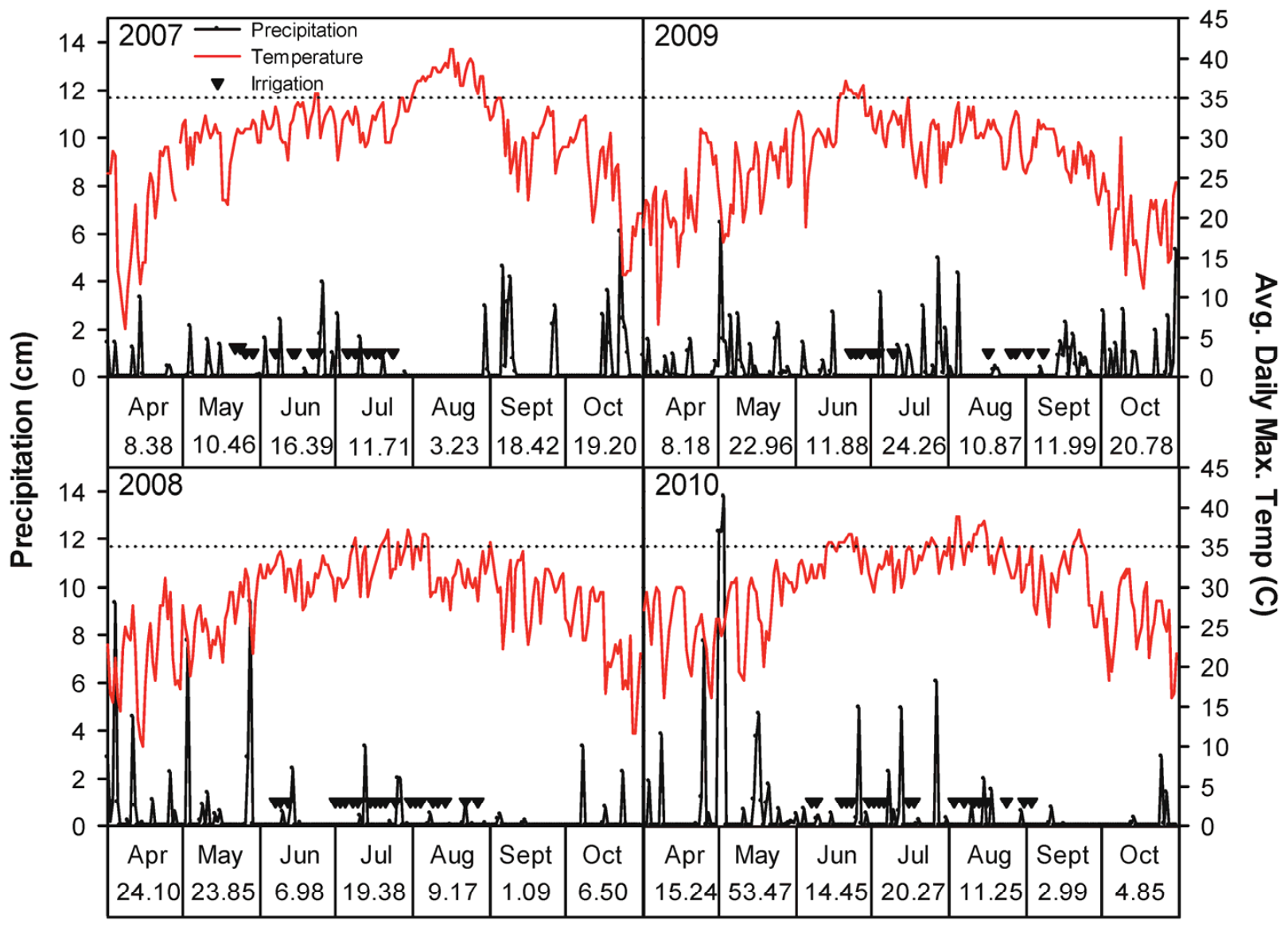

Month and corresponding monthly precipitation and irrigation. total (cm)

Fig. 1. Combined irrigation and total precipitation expressed below each graph and maximum air temperatures for the months of April through October for 2007 to 2010 at Milan, TN. 
The field was divided into three blocks. Half of each block was tilled and the other half was no-till. Alleys separating plots within each tillage type were $1.5 \mathrm{~m}$ in length. The tilled plots were prepared using a Case IH 500 disk set to cut at a depth of approximately $11 \mathrm{~cm}$ in the initial pass. A secondary pass was made to provide efficient soil crushing and mixing. This resulted in a final soil tillage depth of approximately $22 \mathrm{~cm}$. The tillage passes were followed immediately by a Case IH roller harrow to conserve soil moisture and to firm-up the seed bed prior to planting. No-till plots received no preplanting operations, and the desiccated winter weed residues were left undisturbed.

Soybeans were planted at a rate of 12 seeds/m using an Almaco plot planter equipped with John Deere XP row units on 7 May 2007, 1 May 2008, 18 May 2009, and 13 May 2010. Soybeans were irrigated using a center pivot irrigation system distributing approximately $1.0 \mathrm{~cm}$ of water per irrigation event.

The experiment was arranged in a randomized split-split plot design with tillage (till and no-till) as the main plots, soybean cultivars (NKS39K6, Asgrow4403, and Progeny5115) as subplots, and pyraclostrobin treatments ( 0 and 2 applications of $0.24 \mathrm{~kg}$ a.i./ha) as sub-subplots with three replications. Each subplot consisted of four rows spaced $76.2 \mathrm{~cm}$ apart and $6 \mathrm{~m}$ long. Two rows of the frogeye susceptible cultivar, Asgrow4703, were planted between plots to minimize border effect and ensure adequate disease pressure across the research area.

Fungicide applications were made at both R3 and R5 growth stages (R3, pod set, and R5, beginning seed development) using a Spider sprayer equipped with a broadcast spray boom with nozzles set on $50.8-\mathrm{cm}$ centers and fixed to accommodate four $76.2-\mathrm{cm}$ rows. The sprayer was calibrated for an output of 187 liters/ha using Tej XRC 11002 extended range flat fan spray tips at a speed of $4.8 \mathrm{~km} / \mathrm{h}$ with spray pressure of $360 \mathrm{kPa}$. The commercial formulation of pyraclostrobin (Headline, BASF Corp., Research Triangle Park, NC) was used at a rate of $439 \mathrm{ml} / \mathrm{ha}(0.24 \mathrm{~kg}$ a.i./ha) with a surfactant (Induce, Helena Chem. Co., Memphis, TN).

Soybean yield was determined from the two center rows of each sub-subplot at plant maturity. Since the cultivars matured at different times, the plants from MG III and IV cultivars were hand cut and manually fed into a Massey Ferguson plot combine (MF 8XP, Kincaid Equipment Manufacturing Corp., Haven, KS). Yield of the MG V cultivar was determined by harvesting the center two rows of each plot using the same Massey Ferguson 8XP plot combine equipped with a conventional header with sickle bar cutting knife. Seed weight and grain moisture were collected using weigh buckets and a blade-type moisture sensor with the Juniper Systems Harvest Master program (Juniper Systems, Inc., Logan, UT). Harvested seed weight was adjusted to $12 \%$ moisture content to determine yield.

Disease assessment. FLS severity ratings were recorded at each reproductive growth stage (RS) from R1 (first bloom) through R7 (maturity). Each plot was visually rated for FLS severity using a 0 to 9 scale where 0 was no symptoms present and 9 was complete coverage of leaves with FLS lesions $(14,15,27)$. This rating system represents $0=0 \%, 1=10 \%, 2=20 \%, 3=30 \%, 4=40 \%, 5=50 \%$, $6=60 \%, 7=70 \%, 8=80 \%$, and $9=90 \%$ of leaf area affected (27). These values were used to calculate area under the disease progress curve (AUDPC) using the following formula:

$$
\text { AUDPC }=\sum_{i=1}^{n}\left(\frac{x_{i+1}+x_{i}}{2}\right)\left(t_{t+1}-t_{i}\right)
$$

where $x_{i}=$ the proportion of tissue affected (disease severity) at the $i$ th observation, $t=$ time (days), and $n=$ total number of observations. $\Sigma$ is the sum of all of the individual trapezoids or areas from $i$ to $n-1$, and $i+1$ represent observations from 1 to $n$ (31). The ratings were converted into percentages and log-transformed for ANOVA. The AUDPC was standardized by dividing AUDPC by the total length of the disease assessment period in order to make direct comparisons among epidemics over time, across cultivars and years. Standardized AUDPC are presented in tables for simplicity of understanding.
Isolate collection and assessment. Isolates of $C$. sojina collected from the Research and Education Center in Milan in 2007 and 2010 were tested for quinone outside inhibitor (QoI) fungicide resistance (Table 1). In 2007, FLS-infected leaves were collected randomly from research plots in the vicinity of this study, and single spores were isolated and placed on V8 media amended with streptomycin at $150 \mu \mathrm{g} \mathrm{ml}^{-1}$ using a dissecting microscope and needle. Isolates were maintained at approximately $4^{\circ} \mathrm{C}$ and transferred as necessary. In 2013, fresh cultures were incubated on V8 media amended with streptomycin at $150 \mu \mathrm{g} \mathrm{ml}^{-1}$, placed under 12 $\mathrm{h}$ fluorescent and black light $/ 12 \mathrm{~h}$ darkness at $25^{\circ} \mathrm{C}$ for 12 days to produce fresh conidia. Plates were flooded with $5 \mathrm{ml}$ of sterile water and conidia were dislodged using a sterile glass stirring rod. The resulting conidial suspension was filtered through two layers of cheesecloth and used for in vitro germination assay described below. In 2010, FLS-infected leaves were collected randomly from fungicide research plots approximately $150 \mathrm{~m}$ southeast of this study to test for QoI fungicide resistance.

To test for QoI fungicide resistance, sterile distilled water ( $2 \mathrm{ml})$ was placed onto sporulating lesions with a micropipette, and conidia and water were then drawn back up and deposited on a sterile petri plate to create a conidial suspension.

Conidial suspensions from isolates collected in 2007 and 2010 were tested in 2013 using an in vitro conidial germination assay as described by Zhang et al. (37). Briefly, technical-grade azoxystrobin (96\% a.i., Syngenta Crop Protection, Greensboro, $\mathrm{NC}$ ) was used to prepare a stock solution at $100 \mu \mathrm{g} \mathrm{ml}^{-1}$ in acetone. Serial dilutions in acetone were conducted to obtain a final concentration of $1 \mu \mathrm{g} \mathrm{ml}^{-1}$ azoxystrobin and added to potato dextrose agar (PDA) after it cooled to approximately $55^{\circ} \mathrm{C}$. Non-fungicideamended PDA was also included. Salicylhydroxamic acid (SHAM) (Sigma Chemical Co., St. Louis, MO) dissolved in methanol was added to all media at $60 \mu \mathrm{g} \mathrm{ml}^{-1}$ after it cooled to approximately $55^{\circ} \mathrm{C}$. SHAM was added to inhibit alternative respiration in $C$. sojina, as indicated in previous QoI fungicide sensitivity assays (37). Conidial suspensions were divided equally and placed on fungicide amended and unamended plates. After 14 to $18 \mathrm{~h}$, the number of germinated conidia out of 100 was recorded for each plate. Conidia were considered germinated if the germ tube was the same length or greater than the conidium.

Weather data. The average minimum and maximum air temperatures, daily precipitation, and daily irrigation were recorded at the Research and Education Center in Milan, which is part of the National Climatic Data Center of the National Oceanic and Atmospheric Administration (NOAA) (18).

Data analysis. Preliminary analysis of variance (ANOVA) was performed on the data for each year using a general linear mixed model with PROC GLIMMIX procedures in SAS ver. 9.3 (SAS Institute, Cary, NC). The ANOVA contained fixed effects for the tillage, cultivar, and fungicide main effects, and the 2- and 3-way interactions. Random effects were block and block $\times$ tillage. The yield and AUDPC data were combined over years and growth stages (for disease ratings), and a final ANOVA treated years or growth stages as a repeated measure type of sub-subunit. To test tillage, cultivar, and fungicide effects on FLS severity over the 4 years, least squares means were obtained from ANOVA for AUDPC and yield data. Pair-wise mean comparisons were made between various treatment combinations based on the significance of the $F$ test in the ANOVA table. PROC CORR procedure of SAS was used to conduct Pearson's correlation test between AUDPC and yield by cultivars across years. The rate of disease progress for each year-by-tillage-by-fungicide was computed to determine the trend for predicting disease rating.

\section{Results}

These tests were conducted in a field site with a reliable history of FLS infection and under irrigation each year (14). Weather conditions during the cropping seasons in 2007 through 2010 provided favorable conditions for the development of FLS (Fig. 1). Disease was severe in plots each year and had a rating of 5 to 9 (50 to $90 \%$ 
disease severity) on the FLS-susceptible cultivar (Asgrow4703) planted in the border rows, indicating that disease distribution across the test area and year was present. C. sojina isolates collected from the Research and Education Center in Milan in 2010 contained both QoI fungicide-resistant and -sensitive isolates, while 2007 isolates contained only sensitive isolates (Table 1). Although more isolates should have been tested to be indicative of the amount of QoI resistance present in the field, the limited isolates tested indicate that QoI resistant strains were present in 2010. Results from QoI sensitivity testing, using bulk samples of $C$. sojina from the Milan Research and Education Center in 2012, revealed 0 to $15 \%$ of conidia were resistant to QoI fungicides (Carl Bradley, personal communication).

The year, cultivars, and their corresponding maturity (MG), reproductive stages (RS) when disease severity was recorded and during which fungicide applications were made, and the corresponding days after planting are presented in Table 2. On the basis of PROC GLIMMIX, the factors having significant effects on AUDPC and yield are presented in Table 3. Analysis of variance for FLS severity using AUDPC indicated that tillage was not significant as a main effect; however, there was a significant interaction effect of tillage-by-fungicide (Table 3). The main effects of cultivar, fungicide, and year were all significant, as were the inter- actions effect of cultivar-by-year, fungicide-by-year, tillage-byfungicide-by-year, and cultivar-by-fungicide-by-year (Table 3). Analysis of variance for yield also showed that tillage as a main effect was not significant, but there were significant cultivar and year effects, and tillage-by-year and cultivar-by-year interactions (Table 3).

Disease severity progressed slowly for both tilled and no-till plots up to R3 and then rapidly from R4 to R7 for all three cultivars over the 4 years when no fungicide was applied (Fig. 2). FLS severity taken over time fit a quadratic trend with parameters b0, b1, and b2 in the form: Predicted FLS $=b 0+b_{1} \times$ Time $+b_{2} \times$ $\mathrm{RS}^{2}$. This form was generated and contrast comparison between the treated and nontreated was made. The rate of change of disease is presented with different equations for tilled and no-till, treated and nontreated with fungicide for each year. The rate at which disease progressed over RS is further clarified in Figure 3, where the rates of change of disease are presented with different equations for each tillage, treated and nontreated, and year. FLS severity as a function of RS fit a quadratic trend (Rating = Intercept + $\mathrm{b} 1 * \mathrm{RS}=\mathrm{b} 2 * \mathrm{RS}^{2}$ ) where the slope parameters (b1 and b2) jointly define the trend. Contrasts were constructed to test for significance of trends to compare between treated and nontreated. In 2007, the no-till and nontreated has a significant trend. Even though the

Table 2. Soybean cultivars, maturity group (MG), days after planting, and the corresponding reproductive growth stages during which disease severity rating were taken, and R3 and R5 a growth stages when fungicide applications were made in a field study at Milan, TN in 2007 through 2010

\begin{tabular}{|c|c|c|c|c|c|c|c|c|c|c|c|c|}
\hline \multirow[b]{2}{*}{ Year } & \multirow[b]{2}{*}{ Cultivar } & \multirow[b]{2}{*}{ MG } & \multicolumn{8}{|c|}{ Reproductive growth stages } & \multirow{2}{*}{\multicolumn{2}{|c|}{$\begin{array}{l}\text { Fungicide application } \\
\text { DAP at growth stages }\end{array}$}} \\
\hline & & & R1 & $\mathbf{R 2}$ & $\mathbf{R 3}$ & R4 & R5 & R6 & $\mathbf{R 7}$ & R8 & & \\
\hline & & & \multicolumn{8}{|c|}{ Days after planting (DAP) } & $\mathrm{R} 3$ & R5 \\
\hline \multirow{5}{*}{2007} & NKBrandS39K6 & III & 40 & 44 & 63 & 71 & 78 & 85 & 112 & 127 & 63 & 81 \\
\hline & Asgrow4403 & IV & 42 & 46 & 63 & 71 & 78 & 85 & 112 & 127 & 63 & 81 \\
\hline & Progeny 5115 & V & 64 & 71 & 78 & 83 & 85 & 112 & 127 & 141 & 81 & 88 \\
\hline & & & & & & & & & & & $\mathrm{R} 3$ & R5 \\
\hline & NKBrandS39K6 & III & 40 & 48 & 75 & 81 & 89 & 103 & 124 & 138 & 71 & 80 \\
\hline \multirow[t]{4}{*}{2008} & Asgrow4403 & IV & 45 & 49 & 75 & 89 & 96 & 117 & 138 & 147 & 71 & 97 \\
\hline & Progeny 5115 & $\mathrm{~V}$ & 71 & 82 & 89 & 96 & 103 & 124 & 147 & 154 & 90 & 106 \\
\hline & & & & & & & & & & & R3 & R5 \\
\hline & NKBrandS39K6 & III & 43 & 48 & 67 & 72 & 81 & 100 & 114 & 122 & 63 & 80 \\
\hline \multirow[t]{3}{*}{2009} & Asgrow4403 & IV & 43 & 47 & 67 & 72 & 81 & 100 & 122 & 128 & 63 & 80 \\
\hline & Progeny 5115 & $\mathrm{~V}$ & 61 & 67 & 72 & 81 & 86 & 114 & 128 & 134 & $80^{\mathrm{b}}$ & 99 \\
\hline & & & & & & & & & & & R3 & R5 \\
\hline \multirow[t]{3}{*}{2010} & NKBrandS39K6 & III & 40 & 43 & 57 & 71 & 78 & 92 & 112 & 119 & 57 & 83 \\
\hline & Asgrow4403 & IV & 44 & 48 & 57 & 68 & 78 & 99 & 119 & 126 & 57 & 83 \\
\hline & Progeny 5115 & $\mathrm{~V}$ & 59 & 75 & 71 & 85 & 92 & 106 & 126 & 133 & 74 & 96 \\
\hline
\end{tabular}

${ }^{a}$ Growth stage R3 is pod set and R5 is beginning seed development.

${ }^{\mathrm{b}}$ Spray was delayed due to rain event.

Table 3. Probability of greater values of $F$ resulting from Type III tests of fixed effects for area under the disease progress curve (AUDPC) and yield obtained from SAS PROC MIXED analysis ${ }^{\mathrm{a}}$

\begin{tabular}{|c|c|c|c|c|}
\hline \multirow[b]{2}{*}{ Effect } & \multicolumn{2}{|c|}{$\operatorname{AUDPC}\left(\log _{10}\right)$} & \multicolumn{2}{|c|}{ Yield } \\
\hline & $P$ value & $F$ value & $P$ value & $F$ value \\
\hline Tillage (T) & 0.2776 & 2.18 & 0.6587 & 0.26 \\
\hline Cultivar (C) & $0.0025^{*}$ & 8.22 & $<0.0001^{*}$ & 34.28 \\
\hline$(\mathrm{T} \times \mathrm{C})$ & 0.9131 & 0.09 & 0.3128 & 1.23 \\
\hline Fungicide (F) & $0.0011^{*}$ & 14.52 & 0.1585 & 2.15 \\
\hline$(\mathrm{T} \times \mathrm{F})$ & $0.0282 *$ & 5.59 & 0.1143 & 2.73 \\
\hline$(\mathrm{C} \times \mathrm{F})$ & 0.9657 & 0.03 & 0.2929 & 1.31 \\
\hline$(\mathrm{T} \times \mathrm{C} \times \mathrm{F})$ & 0.9578 & 0.04 & 0.5902 & 0.54 \\
\hline Year $(\mathrm{Y})$ & $<0.0001^{*}$ & 67.59 & $0.0041 *$ & 13.96 \\
\hline$(\mathrm{T} \times \mathrm{Y})$ & 0.4108 & 0.97 & $0.0237 *$ & 3.37 \\
\hline$(\mathrm{C} \times \mathrm{Y})$ & $0.0274 *$ & 2.56 & $<0.0001^{*}$ & 37.03 \\
\hline$(\mathrm{T} \times \mathrm{C} \times \mathrm{Y})$ & 0.7663 & 0.55 & 0.8634 & 0.42 \\
\hline$(\mathrm{F} \times \mathrm{Y})$ & $0.0004 *$ & 6.90 & 0.5821 & 0.66 \\
\hline$(\mathrm{T} \times \mathrm{F} \times \mathrm{Y})$ & $0.0062 *$ & 4.50 & 0.3196 & 1.19 \\
\hline$(\mathrm{C} \times \mathrm{F} \times \mathrm{Y})$ & $0.0022 *$ & 3.88 & 0.4362 & 0.99 \\
\hline$(\mathrm{T} \times \mathrm{C} \times \mathrm{F} \times \mathrm{Y})$ & 0.9437 & 0.28 & 0.8022 & 0.51 \\
\hline
\end{tabular}

${ }^{a}$ The MIXED procedure of SAS was performed where the fixed effects are the main effects and all interactions of tillage, cultivar, fungicide and year. The random effects, each nested in tillage, are block (rep), rep $\times$ tillage, rep $\times$ tillage $\times$ cultivar, rep $\times$ fungicide, rep $\times$ tillage $\times$ fungicide, rep $\times$ year/rep $\times$ tillage $\times$ year $/$ rep $\times$ tillage. $*$ indicates significant effect $(P \leq 0.05)$. 
treated showed a significant trend, it was not as significant as the nontreated. The rate of disease progress in no-till and nontreated plots was significantly greater in no-till 2007, 2009, and 2010, while it was slightly greater in till and treated plots in 2008 and 2010.

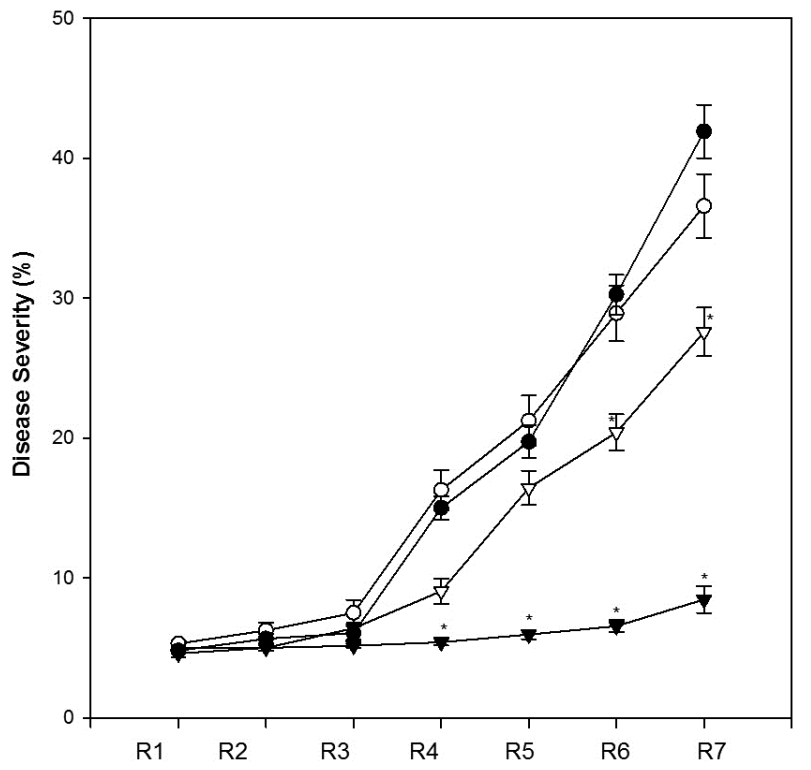

Fig. 2. Disease severity ratings of frogeye leaf spot in tilled and no-fungicide (filled circle), no-till and no-fungicide (open circle), no-till with fungicide (open triangle), and tilled with fungicide (filled triangle) plots in a field study at Milan, TN in 2007 to 2010. The * symbol indicates when fungicide effect showed significant difference $(P \leq 0.05)$.
Even though the main effect of tillage was not significant, the interaction between tillage and fungicide treatment was significant and the least square means comparison across all cultivars and years indicate fungicide treatment in tilled plots resulted in significantly reduced AUDPC, whereas fungicide did not result in a significantly reduced AUDPC in no-till plots (Table 4). Further analysis of disease progress between fungicide treated and nontreated plots within tilled treatments indicates fungicide significantly reduced disease severity at growth stage R5 through R7 (Fig. 2). This is earlier than in no-till plots in which fungicide significantly reduced disease severity at growth stages R6 through R7 (Fig. 2), although this reduction did not significantly affect AUDPC in notill plots in any year (Table 4). Least square mean separation for cultivar-by-year-by-fungicide indicates fungicide resulted in significantly lowered AUDPC in 2007 for NKS39K6, in 2007 and 2010 for Asgrow4403, and in 2008 for Progeny5115 (Table 4). Across cultivars, there was no significant effect of fungicide-byyear on AUDPC in no-till plots, but there was significantly lower AUDPC in tilled plots within each year (Table 4).

The effects of year on disease severity using the disease ratings taken at each RS and AUDPC for each cultivar are further clarified in Figure 2 and Table 5. The AUDPC had a range of 9 to 33 among the three cultivars over the 4 years, indicating significant environmental differences among years. In 2010, Asgrow4403 and Progeny5115, later maturing cultivars, had the greatest AUDPC and the lowest yields across years within each cultivar (Table 5). There was no significant difference in AUDPC for later maturing cultivars in 2007 through 2009. AUDPC was negatively correlated to yield in the later maturing varieties, with a correlation coefficient of -0.52 $(P=0.0002)$ for Asgrow4403 and -0.59 for Progeny5115 $(P<$ $0.0001)$. The earliest maturing cultivar, NKS39K6, differed in

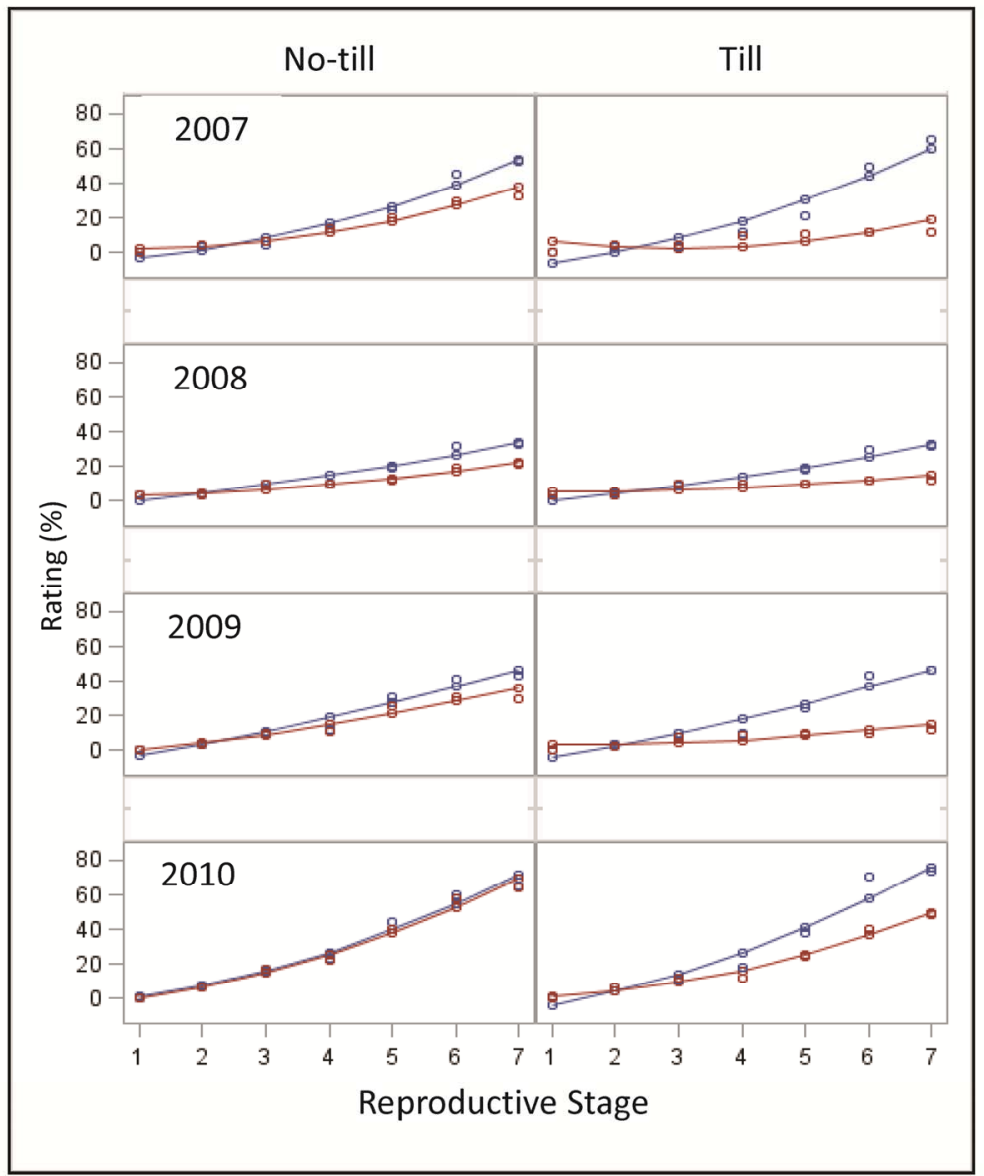

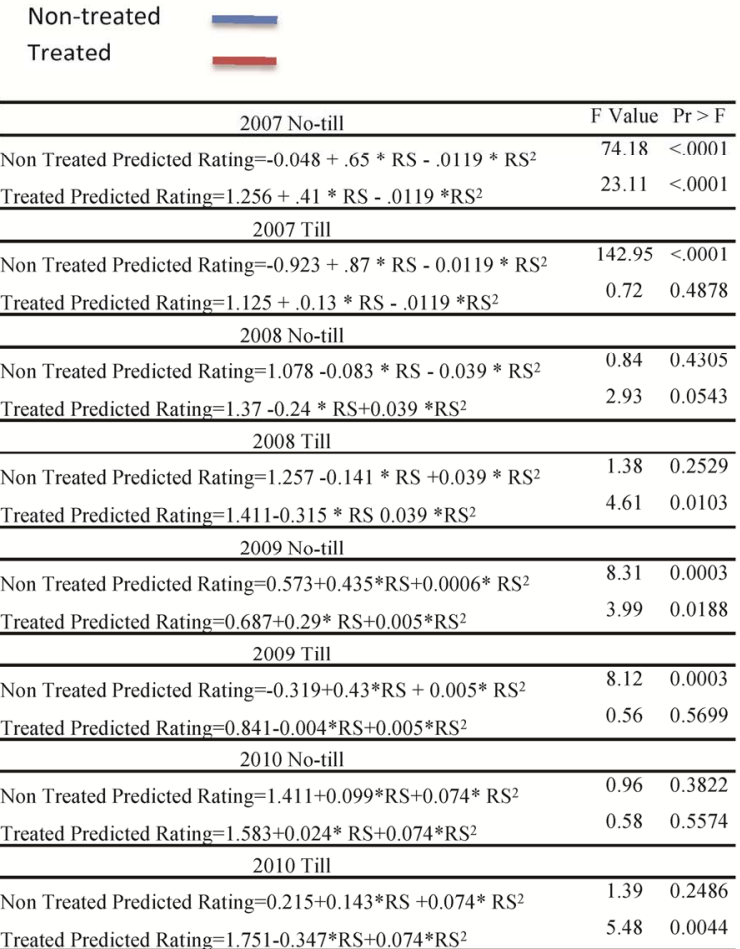

Fig. 3. Disease progress according to a quadratic model for 16 disease trends with different levels of disease intensity on data collected over time from 2007 through 2010 The quadratic trend is of the form: Predicted rating $=$ Intercept $+b_{1}{ }^{*}$ Reproductive Stage $(R S)+b_{2}{ }^{*} R S^{2}$. There are 16 trends, one for each year $\times$ tillage $\times$ fungicide combination. 
yearly trends in AUDPC and yield compared to the later maturing cultivars. In 2008, NKS39K6 had the numerically lowest AUDPC and yield across all tillage and fungicide treatments (Table 5). AUDPC was positively correlated to yield for NKS39K6 with a correlation coefficient of $0.31(P=0.0323)$. Across cultivars within years, Progeny5115 had significantly greater AUDPC and disease rating taken at each RS than NKS39K6 $(P \leq 0.05)$ and Asgrow4403 $(P \leq 0.02)$ across treatments in 2008 through 2010 (Fig. 4 and Table 5). NKS39K6 had significantly lower yield than Asgrow4403 and Progeny5115 in 2008 and 2009 (Table 5). When the interaction effect of tillage-by-year was assessed, yield was signifi-

Table 4. Least square means for cultivar-by-year-by-fungicide ${ }^{a}$ and tillageby-year-by-fungicide ${ }^{\mathrm{b}}$ interactions for area under the disease progress curve $\left(\mathrm{AUDPC}^{\mathrm{c}}\right)$

\begin{tabular}{|c|c|c|c|}
\hline & \multirow[b]{2}{*}{ Year } & \multicolumn{2}{|c|}{ AUDPC } \\
\hline & & Treated & Nontreated \\
\hline \multirow[t]{4}{*}{ No-till } & 2007 & 16 & 22 \\
\hline & 2008 & 11 & 15 \\
\hline & 2009 & 13 & 16 \\
\hline & 2010 & 25 & 26 \\
\hline \multicolumn{4}{|l|}{$\mathrm{LSD}=6.4$} \\
\hline \multirow[t]{4}{*}{ Tilled } & 2007 & 8 & 24 \\
\hline & 2008 & 8 & 14 \\
\hline & 2009 & 6 & 15 \\
\hline & 2010 & 17 & 26 \\
\hline \multicolumn{4}{|l|}{$\mathrm{LSD}=3.3$} \\
\hline \multirow[t]{4}{*}{ NKS39K6 } & 2007 & 10 & 25 \\
\hline & 2008 & 9 & 9 \\
\hline & 2009 & 8 & 13 \\
\hline & 2010 & 15 & 19 \\
\hline \multicolumn{4}{|l|}{$\mathrm{LSD}=4.6$} \\
\hline \multirow[t]{4}{*}{ Asgrow4403 } & 2007 & 7 & 16 \\
\hline & 2008 & 8 & 13 \\
\hline & 2009 & 8 & 12 \\
\hline & 2010 & 17 & 24 \\
\hline \multicolumn{4}{|l|}{$\mathrm{LSD}=3.9$} \\
\hline \multirow[t]{4}{*}{ Progeny5115 } & 2007 & 18 & 26 \\
\hline & 2008 & 12 & 22 \\
\hline & 2009 & 12 & 20 \\
\hline & 2010 & 31 & 35 \\
\hline
\end{tabular}

$\mathrm{LSD}=6.5$

${ }^{a}$ Least significant difference values $(P \leq 0.05)$ indicate pair-wise comparisons between treated and nontreated means within tillage type across cultivars.

${ }^{\mathrm{b}}$ Least significant difference values $(P \leq 0.05)$ indicate pair-wise comparisons between treated and nontreated means within tillage type across tillage.

c AUDPC was standardized by dividing AUDPC by total length of disease assessment period. cantly greater $(P \leq 0.05)$ in 2007 and 2009 than in 2008 and 2010 in both till and no-till (Table 6).

Although fungicide treatment did not have a statistically significant effect on yield across cultivars and years (Table 3), there were consistent yield increases in tilled but not in no-till plots across years and cultivars in response to fungicide treatments (Table 7). Comparing yield from fungicide treated and nontreated plots in notill cultivation, Progeny5115 had greater yield in treated plots every year, Asgrow4403 had lower yield in treated plots every year, and NKS39K6 had greater yield in treated plots in 2 of the 4 years (Table 7). Overall, yield improved in only 6 out of 12 comparisons when fungicide was applied in no-till plots. In tilled plots across all years and cultivars, all fungicide treatment resulted in greater yield than nontreated, tilled plots (12 out of 12 comparisons). The percent increase in yield in fungicide treated, tilled plots over nontreated, tilled plots ranged between 2 and 10\%, 1 and 17\%, and 4 and 14\%, with NKS39KS, Asgrow4403, and Progeny5115, respectively. No-till plots had greater yield over tilled plots in 9 out of 12 comparisons when not treated with fungicide (Table 7).

\section{Discussion}

In this study, in the absence of fungicide application, disease progress for FLS between no-till and tilled plots was not significantly different, indicating that no-till did not enhance or reduce the severity of FLS across 4 years and three cultivars (Fig. 2). The quadratic model provided a fit to the FLS disease progress curve (Fig. 3) and can be useful for prediction, systems analyses, and simulation on analog and digital computers.

The historical practice of burying plant residues has been promoted to reduce soil- and debris-born plant pathogens $(4,28)$ and has led to cultural practices involving shallow and deep plowing to bury residue. Since $C$. sojina survives in residue, cultural practices like tillage were aimed at reducing inoculum on residue and assist in the control of FLS. The relatively shallow tillage in this study (22 $\mathrm{cm}$ deep) is representative of more popular conservation tillage that is acceptable in high soil erosion areas of Tennessee. The fact that no significant difference in disease severity was detected between till and no-till when fungicide was not applied suggests that shallow conservation tillage is not deep enough to enhance debris deterioration and reduce $C$. sojina inoculum. This is in agreement with a previous report from Illinois, where viable $C$. sojina inoculum was recovered from infected soybean leaves placed at depths of 0,10 , and $20 \mathrm{~cm}$ and retrieved after 12 and 19 months (35). $C$. sojina was not recovered from two of three locations where the study was conducted only after 24 months, regardless of depth in soil, which suggests that rotating to a nonhost crop for 2 years would be the most significant practice to reduce the level of $C$. sojina inoculum. Similar results were reported in Ohio, where $C$. sojina survived during the winter of 2007-2008 in naturally in-

Table 5. Least square means for cultivar-by-year interactions for area under the disease progress curve (AUDPC) and yield, with analysis across years within cultivars $^{\mathrm{a}}$ and analysis across cultivars within years ${ }^{\mathrm{b}}$

\begin{tabular}{|c|c|c|c|c|c|c|c|c|}
\hline & \multicolumn{4}{|c|}{ AUDPC $^{c}$} & \multicolumn{4}{|c|}{ Yield (kg/ha) } \\
\hline & NKS39K6 & & Asgrow4403 & Progeny5115 & NKS39K6 & & Asgrow4403 & Progeny5115 \\
\hline 2007 & 18 & & 12 & 22 & 4,565 & & 4,511 & 4,108 \\
\hline 2008 & 9 & & 10 & 17 & 1,554 & & 4,767 & 4,701 \\
\hline 2009 & 11 & & 10 & 16 & 3,815 & & 4,259 & 4,494 \\
\hline 2010 & 17 & & 20 & 33 & 2,832 & & 3,200 & 3,106 \\
\hline \multirow[t]{2}{*}{ LSD } & 4 & & 4 & 8 & 491 & & 319 & 395 \\
\hline & 2007 & 2008 & 2009 & 2010 & 2007 & 2008 & 2009 & 2010 \\
\hline NKS39K6 & 18 & 9 & 11 & 17 & 4,565 & 1,554 & 3,815 & 2,832 \\
\hline Asgrow4403 & 12 & 10 & 10 & 20 & 4,511 & 4,767 & 4,259 & 3,200 \\
\hline Progeny5115 & 22 & 17 & 16 & 33 & 4,108 & 4,701 & 4,494 & 3,106 \\
\hline LSD & 7 & 4 & 4 & 5 & 490 & 599 & 374 & 418 \\
\hline
\end{tabular}

${ }^{a}$ The least significant difference values $(P \leq 0.05)$ indicate pair-wise comparisons between treated and nontreated means across years within cultivars.

${ }^{\mathrm{b}}$ The least significant difference values $(P \leq 0.05)$ indicate pair-wise comparisons between treated and nontreated means across cultivars within years.

${ }^{c}$ AUDPC was standardized by dividing AUDPC by the total length of the disease assessment period. 
fested crop residue on the surface of field plots, which most likely contributed to increased incidence of FLS in Ohio the following year (6). Another explanation for similar disease severity in tilled and no-till plots is that inoculum from other sources, such as bordering rows, neighboring fields, and inoculum from possible weedy hosts could be influencing FLS development and severity. Additional research is needed to determine the impact between different sources of inoculum.

Although tillage alone did not significantly affect disease, tillage resulted in increased fungicide efficacy when compared to fungicide treatment in no-till (Table 4). AUDPC across cultivars was not significantly reduced by fungicide in no-till plots in any of the 4 years of the trial, while fungicides were effective in reducing disease in tilled plots every year under high disease pressure (Table 4). Although there were no significant differences in disease severity between tillage systems in the absence of fungicide, the significant interaction between tillage and fungicide indicates there was less inoculum in tilled, fungicide-treated plots.
Although adequate disease pressure occurred every year, yearly differences in AUDPC are most likely due to varying precipitation and temperatures that occurred during the study. The warmer temperatures and greater precipitation and irrigation from May through September in 2007 and 2010 (Fig. 1) provided the most conducive conditions for FLS disease development and resulted in the greatest AUDPC and disease severity across cultivars, tillage, and fungicide treatments (Tables 4 and 5). In 2008 and 2009, cooler temperatures most likely limited disease development and reduced FLS severity compared to 2007 and 2010 (Fig. 3).

Differences in yield and AUDPC across cultivars in both tilled and no-till plots may be due to maturity differences (Tables 2 and $5)$. Differences in maturity may interact with the developing disease and environmental factors (i.e., having different environmental conditions at the different growth stages for each cultivar within each maturity group). For example, NKS39K6 had the lowest AUDPC and the lowest yield in 2008, which is most likely due to disease not affecting yield negatively because of the early matura-
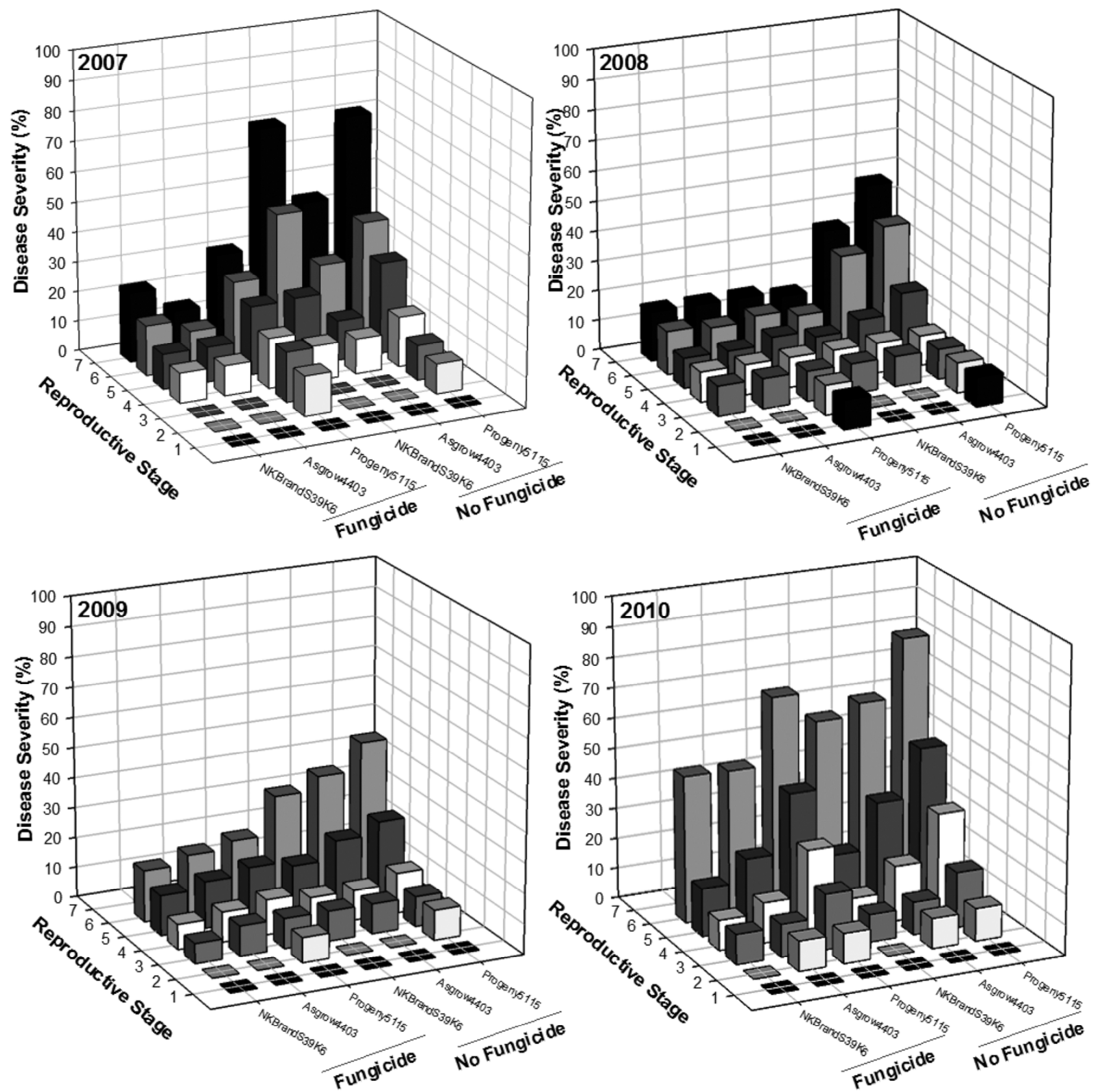

Fig. 4. 3D representation of frogeye leaf spot severity progression measured at each growth stage for three cultivars, NKS39K6 (MG3), Asgrow4403 (MG4), and Progeny 5115 (MG 5), treated and nontreated across tillage for each year from 2007 through 2010. 
tion of the cultivar (Tables 2 and 5). However, the later maturing varieties had the lowest yields and greatest AUDPC in 2010; and their yields were negatively correlated with AUDPC (correlation coefficient between AUDPC and yield across years for Asgrow4403 $=-0.52, P=0.0002$; for Progeny5115 $=-0.59, P<$ $0.0001)$. Within years and across cultivars, Progeny5115 had significantly greater AUDPC in 2008 and 2010, but only significantly greater yield than NKS39K6 in 2008 and 2009 (Table 5). Fungicide treatment significantly reduced disease in 2007 on cultivars NKS39K6 and Asgrow4403, and in 2010 on Asgrow4403, which were years with the greatest disease, whereas fungicide treatment reduced disease severity in 2008 on cultivar Progeny5115 (Table 4).

Fungicide application reduced disease severity by approximately $78 \%$ at R7 growth stage in tilled plots and only $24 \%$ in no-till plots, which would usually be attributed to greater level of inoculum in no-till plots, but in this study, tilled and no-till plots had the same level of disease in the absence of fungicide (Figs. 2 and 3). Similarly, fungicide reduced severity at an early growth stage, R5, in tilled plots compared to R6 in no-till plots. The fact that a fungicide effect was detected much earlier at R5 in tilled plots compared to later at R6 in no-till may indicate lowered competition from other fungi/microorganisms. Other plant-pathogenic fungi have reduced disease severity due to competition with other fungi. For example, competition in rust fungi resulted in crowding and can reduce both their efficiency in forming sporulating pustules and the numbers of spores they produce per pustule (10). Furthermore, the difference in tillage-by-fungicide interaction is most likely influenced by different environmental conditions in tilled and no-till plots. In particular, moisture is known to be retained more in no-till cultivation (17), possibly allowing for a stronger, more established

Table 6. Least square means of tillage-by-year interactions for yield $(\mathrm{kg} / \mathrm{ha})^{\mathrm{a}}$

\begin{tabular}{lcc}
\hline & Year & Yield (kg/ha) \\
\hline No-till & 2007 & 4,455 \\
& 2008 & 3,474 \\
& 2009 & 4,318 \\
LSD = 726 & 2010 & 3,170 \\
Tilled & & \\
& 2007 & 4,336 \\
& 2008 & 3,874 \\
LSD $=631$ & 2009 & 4,061 \\
& 2010 & 2,924
\end{tabular}

${ }^{a}$ Least significant difference values $(P \leq 0.05)$ indicate pair-wise comparisons between treated and non-treated plots within tillage type across cultivars. infection, although not greater in severity or incidence compared to tilled plots in the absence of fungicide. Another possible explanation for the significant fungicide effect in tilled plots but not in notill plots is that the type of cultivation may be selecting for different populations of $C$. sojina, including fungicide resistant strains.

Further research investigating the possibility that strains of $C$. sojina resistant to the quinone outside inhibitor (QoI or strobilurin) fungicide group or more aggressive $C$. sojina populations may be more readily selected in no-till cultivation over tilled is needed. QoI fungicide resistant strains may survive at higher proportions in no-till compared to tilled cultivation. The possible selection of QoI resistant strains in no-till cultivation may explain the lack of significant decrease in severity in no-till plots compared to tilled plots treated with pyraclostrobin, a QoI fungicide (Table 4). QoI resistant strains were discovered in Milan in 2010; although the few isolates collected in 2007 were sensitive to QoI fungicides, this does not exclude the possibility that QoI resistant strains were present in Milan throughout the duration of the study (Table 1). Furthermore, the three out of four QoI resistant strains collected in 2010 is not indicative of the amount of QoI resistance present in the field, only an indication that QoI resistant strains were present. Results from QoI sensitivity testing, using bulk samples of $C$. sojina from the Milan Research and Education Center, in 2012 revealed only 0 to $15 \%$ of conidia were resistant to QoI fungicides (Carl Bradley, personal communication). Hence, it can be speculated that while QoI resistant strains were present in 2010, they were not the dominant strain present.

Control of FLS may require the use of fungicides with different modes of actions and/or additional cultural practices to reduce disease severity and increase yield. FLS is caused by a highly variable pathogen with many races (25), and no-till may provide the conditions for variation and select for fungicide resistant isolates, thus complicating fungicide recommendations. Studies conducted on alternative fungicide groups and using combination fungicides for controlling FLS caused by QoI fungicide-resistant $C$. sojina indicate that fungicides in the triazole (demethylation inhibitor; DMI) and benzimidazole (methyl benzimidazole carbamate; MBC) groups are effective (Carl Bradely, personal communication). However, the use of host resistance $(14,15,19,20,22)$ without the additional risk or concern of new $C$. sojina strains is an alternative for lasting and effective FLS management.

Even though statistical comparisons cannot be made for the interaction between tillage-by-cultivar-by-fungicide-by-year for yield, relevant biological interpretation may be drawn to measure the trends of treatment effects. When paired comparisons between yields were made, there were yield advantages across all comparisons in tilled, fungicide-treated plots over nontreated plots, whereas only $50 \%$ of the comparisons in no-till fungicide treated

Table 7. Least square means for cultivar-by-year-by-fungicide interactions for yield $(\mathrm{kg} / \mathrm{ha})^{\mathrm{a}}$

\begin{tabular}{|c|c|c|c|c|c|c|c|}
\hline & \multirow[b]{2}{*}{ Year } & \multicolumn{2}{|c|}{ Tilled yield (kg/ha) } & \multirow[b]{2}{*}{$\%$ Yield difference } & \multicolumn{2}{|c|}{ No-till yield (kg/ha) } & \multirow[b]{2}{*}{$\%$ Yield difference } \\
\hline & & Treated & Nontreated & & Treated & Nontreated & \\
\hline \multirow[t]{5}{*}{ NKS39K6 } & 2007 & 4,509 & 4,409 & 2 & 4,000 & 5,344 & -33 \\
\hline & 2008 & 1,860 & 1,670 & 10 & 1,601 & 1,084 & 32 \\
\hline & 2009 & 3,849 & 3,635 & 6 & 3,852 & 3,925 & -2 \\
\hline & 2010 & 2,705 & 2,598 & 4 & 3,097 & 2,931 & 5 \\
\hline & & \multicolumn{2}{|c|}{$\mathrm{LSD}=768$} & \multicolumn{4}{|c|}{$\mathrm{LSD}=1364$} \\
\hline \multirow[t]{5}{*}{ Asgrow4403 } & 2007 & 4,795 & 4,183 & 14 & 4,463 & 4,605 & -3 \\
\hline & 2008 & 4,825 & 4,783 & 1 & 4,572 & 4,889 & -7 \\
\hline & 2009 & 4,167 & 3,708 & 11 & 4,578 & 4,586 & 0 \\
\hline & 2010 & 3,276 & 2,723 & 17 & 3,176 & 3,628 & -47 \\
\hline & & \multicolumn{2}{|c|}{$\mathrm{LSD}=671$} & \multicolumn{4}{|c|}{$\mathrm{LSD}=847$} \\
\hline \multirow[t]{5}{*}{ Progeny5115 } & 2007 & 4,291 & 3,825 & 11 & 4,207 & 4,110 & 2 \\
\hline & 2008 & 5,164 & 4,941 & 4 & 4,530 & 4,170 & 8 \\
\hline & 2009 & 4,831 & 4,178 & 14 & 4,695 & 4,274 & 9 \\
\hline & 2010 & 3,341 & 2,898 & 13 & 3,359 & 2,828 & 16 \\
\hline & & \multicolumn{2}{|c|}{$\mathrm{LSD}=959$} & \multicolumn{4}{|c|}{$\mathrm{LSD}=872$} \\
\hline
\end{tabular}

${ }^{a}$ The least significant difference values $(P \leq 0.05)$ indicate pair wise comparisons between treated and non-treated plots within cultivars and tillage. 
plots resulted in a yield increase (Table 7). This is consistent with other research (On Farm Network of Iowa Soybean Association, Pioneer Hi-Bred International, and Iowa State University) that indicates fungicide application is profitable about $50 \%$ of the time in no-till plots. The observed positive yield responses to fungicide in tilled plots may be more predictable than in no-till plots, but these yields were not significantly different $(P<0.05)$ across fungicide treated and nontreated comparisons (Table 7). Paired comparisons between nontreated tilled and nontreated no-till plots showed that no-till plots had a yield advantage over tilled plots across $75 \%$ of the comparisons, indicating that adequate availability of moisture in no-till plots may have provided a better environment for plant growth and improved yield (Table 7). The yield advantage in nontreated, no-till treatments may also be due to a cooler soil temperature from a high volume of crop residue on the soil surface (17).

Results from this study indicate that in the absence of fungicide, no-till plots did not reduce or enhance the severity of FLS compared to tilled plots. The fact that significant reduction in disease severity was not detected in no-till treated plots indicates that there may be a continuous shower of spores from debris to cause frequent infection compared to tilled, treated plots. This may have caused a higher disease severity in treated and no-till plots. This study is the first to report disease severity in side-by-side comparison of no-till and tilled plots under similar environments, showing that tilled plots may not reduce $C$. sojina inoculum and resulting FLS disease under high disease pressure environments. The recommendation to reduce FLS severity by tillage needs to be reconsidered in light of this study. Furthermore, this study indicates that planting soybean in tilled soil had a yield advantage and lower disease severity than in no-till plots when treated with fungicide. This suggests that fungicide programs are beneficial in till systems and that fungicide programs under no-tillage systems may require further study to minimize the risk of FLS. The implication of these findings is that fungicide applications in tilled fields may assist in reducing FLS severity, increase yield, and may possibly reduce the problem of fungicide resistance.

\section{Acknowledgments}

We thank Debbie Boykin, USDA-ARS Mid-South Area Statistician, for her assistance in data analysis and Carl Bradley, University of Illinois, for his contribution to $C$. sojina isolates and QoI fungicide screening. This research was funded by the United State Department of Agriculture (USDA), Agricultural Research Service project number 6402-21220-011-00D and by the Tennessee Soybean Promotion Board. We thank Jamie Jordan, Jason Deffenbaugh, Chris Street, and Tara Sydboten for their assistance in the field and laboratory tests. Mention of trade names or commercial products is solely for the purpose of providing specific information and does not imply recommendation or endorsement by USDA. USDA is an equal opportunity provider and employer.

\section{Literature Cited}

1. Akem, C. N. 1995. The effect of timing of fungicide applications on control of frogeye leaf spot and grain yield of soybeans. Eur. J. Plant Pathol. 101:183-187.

2. Akem, C. N., and Dashiell, K. E. 1994. Effect of planting date on severity of frogeye leaf spot and grain yield of soybeans. Crop Prot. 13:607-610.

3. Athow, K. L. 1987. Fungal diseases. Pages 687-727 in: Soybean: Improvement, production, and uses. 2nd ed. J. R. Wilcox, ed. Agron. Monogr. 16. ASA, CSSA, and SSSA, Madison, WI.

4. Boosalis, M. G., Doupnik, B. L., Jr., and Odvody, G. N. 1981. Conservation tillage in relation to plant diseases. Pages 445-474 in: Handbook of Pest Management in Agriculture. Vol. 1. D. Piementel, ed. CRC Press, Boca Raton, FL.

5. Bradley, A. C., Zhang, G., Chapara, V., Ming, R., Zeng, F., Young, H., Kelly, Y. H., and Newman, N. 2013. Update on detection and management of QoI fungicide resistant Cercospora sojina, the causal agent of frogeye leaf spot in soybean. Proc. 2013 SSDW Meeting, Pensacola, FL.

6. Cruz, C. D., and Dorrance, A. E. 2009. Characterization and survival of Cercospora sojina in Ohio. Online. Plant Health Progress doi:10.1094/ PHP-2009-0512-03-RS

7. Dorrance, A. E., Cruz, C., Mills, D., Bender, R., Koenig, M., LaBarge, G., Leeds, R., Mangione, D., McCluer, G., Ruhl, S., Siegrist, H., Sundermeier, A., Sonnenberg, D., Yost, J., Watters, H., and Wilson, G. 2010. Effects of foliar fungicide and insecticide applications on soybean in Ohio. Plant Health Progress doi:10.1094/PHP-2010-0122-01-RS

8. Fehr, W. R., Caviness, C. E., Burmood, D. T., and Pennington, J. S. 1971.
Stage of development descriptions for soybeans, Glycine max (L.) Morrill. Crop Sci. 11:929-931

9. Grau, C. R., Dorrance, A. E., Bond, J., and Russin, J. S. 2004. Fungal diseases. Pages 732-734 in: Soybeans: Improvement, Production, and Uses, 3rd ed. H. R. Boerma and J. E. Specht, eds. Agron Monogr. 16. ASA, CSSA, and SSSA, Madison, WI.

10. Kardin, M. K., and Groth, J. V. 1989. Density-dependent fitness interactions in the bean rust fungus. Phytopathology 79:409-412.

11. Latterrel, F. M., and Rossi, A. E. 1983. Gray leaf spot of corn: A disease on the move. Plant Dis. 67:102-104.

12. Laviolette, F. A., Athow, K. L., Probst, A. H., Wilcox, J. R., and Abney, T. S. 1970. Effect of bacterial pustule and frogeye leaf spot on yield of Clark soybean. Crop Sci. 10:410-419.

13. Melchers, L. E. 1925. Diseases of cereal and forage crops in the United States in 1924. Plant Dis. Rep. Suppl. 40:180.

14. Mengistu, A., Bond, J., Mian, M. A. R., Nelson, R., Shannon, G., and Wrather, A. 2012. Resistance to frogeye leaf spot in selected soybean accessions in MG I through MG VI. Online. Plant Health Progress doi:10.1094/PHP-2012-0521-02-RS

15. Mengistu, A., Bond, J., Mian. R., Nelson, R., Shannon, G., and Wrather, A 2011. Identification of soybean accessions resistant to Cercospora sojina by field screening, molecular markers, and phenotyping. Crop Sci. 51: 11011109.

16. Mengistu, A., Kurtzweil, N. C., and Grau, C. R. 2002. First report of frogeye leaf spot (Cercospora sojina) in Wisconsin. Plant Dis. 86:1272.

17. Mengistu, A., Reddy, K. N., Zablotowicz, R. M., and Wrather, A. J. 2009 Propagule densities of Macrophomina phaseolina in soybean tissue and soil as affected by tillage, cover crop, and herbicide. Online. Plant Health Progress doi:10.1094/PHP-2009-0130-01-RS

18. Menne, M. J., Durre, I., Vose, R. S., Gleason, B. E., and Houston, T. G. 2012. An Overview of the Global Historical Climatology Network-Daily Database. J. Atmos. Oceanic Technol. 29:897-910.

19. Mian, M. A. R., Boerma, H. R., Phillips, D. V., Kenty, M. M., Shannon, G., Shipe, E. R., Soffes Blount, A. R., and Weaver, D. B. 1998. Performance of frogeye leaf spot resistant and susceptible near isolines of soybean. Plant Dis. 82:1017-1021.

20. Mian, M. A. R., Missaoui, A. M., Walker, D. R., Phillips, D. V., and Boerma, H. R. 2008. Frogeye leaf spot of soybean: A review and proposed race designations for isolates of $C$. sojina Hara. Crop Sci. 48:14-24.

21. Mian, M. A. R., Wang, T., Phillips, D. V., Alvernaz, J., and Boerma, H. R. 1999. Molecular mapping of the Rcs 3 gene for resistance to frogeye leaf spot in soybean. Crop Sci. 39:1687-1691.

22. Mian, R., Bond, J., Joobeur, T., Mengistu, A., Wiebold, W., Shannon, G., and Wrather, A. 2009. Identification of soybean genotypes resistant to Cercospora sojina by field screening and molecular markers. Plant Dis. 93:408-411.

23. Nutter, F. W., Teng, P. S., and Royer, M. H. 1993. Terms and concepts for yield, crop loss and disease threshold. Plant Dis. 77: 211-215.

24. Payne, G. A., Duncan, H. E., and Adkins, C. R. 1987. Influence of tillage on development of gray leaf spot and number of airborne conidia of Cercospora Zeae-maydis. Plant Dis. 71:329-332

25. Phillips, D. V. 1999. Frogeye leaf spot. Pages 20-21 in: Compendium of Soybean Diseases, 4th ed. G. L. Hartman et al., ed. American Phytopathological Society, St. Paul, MN.

26. Sherwin, H. S., and Kreitlow, K. W. 1952. Discoloration of soybean seeds by the frogeye fungus, Cercospora sojina. Phytopathology 42:560-572.

27. Sinclair, J. B., ed. 1982. Introduction. Pages 1-2 in: Compendium of Soybean Diseases, 2nd ed. American Phytopathological Society, St. Paul, MN.

28. Sumner, D. R., Doupnik, B. L., Jr., and Boosalis, M. G. 1981. Effects of reduced tillage and multiple cropping on plant diseases. Annu. Rev. Phytopathol. 19:167-187.

29. Swoboda, C., and Pedersen, P. 2009. Effect of fungicide on soybean growth and yield. Agron. J. 101:352-356.

30. Tekwa, I. J., and Belel, M. D. 2009. Impacts of Traditional Soil Conservation Practices in Sustainable Food Production. Journal of Agriculture and Social Sciences ISSN Print: 1813-2235; ISSN Online: 1814-960X 08038/AWB/2009/5-4-128-130. http://www.fspublishers.org

31. Vidhyasekaran, P. 2004. Concise Encyclopedia of Plant Pathology. Food Products Press and The Haworth Reference Press, Binghamton, NY

32. Walker, J. T., Phillips, D. V., Melin, J., and Spradlin, D. 1994. Effect of intermittent acidic irrigation on soybean yields and frogeye leaf spot. Environ. Exp. Bot. 34:311-318.

33. Wrather, J. A., and Koenning, S. R. 2006. Estimates of disease effects on soybean yields in the United States 2003-2005. J. Nematol. 38:173-180.

34. Yang, X. B., Uphoff, M. D., and Sanogo, S. 2001. Outbreaks of soybean frogeye leaf spot in Iowa. Plant Dis. 85:443.

35. Zhang, G. R. 2012. Cercospora sojina: Over-winter survival and fungicide resistance. Ph.D diss. Crop Science Department, University of Illinois, Urbana-Champaign.

36. Zhang, G. R., Newman, M. A., and Bradley, C. A. 2012. First report of the soybean frogeye leaf spot fungus (Cercospora sojina) resistant to quinone outside inhibitor fungicides in North America. Plant Dis. 96:767.

37. Zhang, G. R., Pedersen, D. K., Phillips, D. V., and Bradley, C. A. 2012. Sensitivity of Cercospora sojina isolates to quinone outside inhibitor fungicides. Crop Prot. 40:63-68. 